\title{
Statistical information: facts and figures
}

(A section where newly issued statistical information of general interest and announcements may be communicated to our readers)

\section{East-West Investment Statistics}

The Trade Division of the Economic Commission for Europe (UN/ECE) publishes four times annually a periodical called East-West Investment News. The publication reviews recent legislation concerning foreign investment in the Central and Eastern European countries and the CIS countries, and presents statistical information on the general developments as well as selected detailed analysis of foreign investment in these countries. An example of the statistical information contained in the publication is given below.

The data now available from most of the European transition economies (TEs) permit to shed some light on the foreign direct investment (FDI) growth in 1994 (see Fig. 1). It should be emphasized that for most countries, the information is not yet

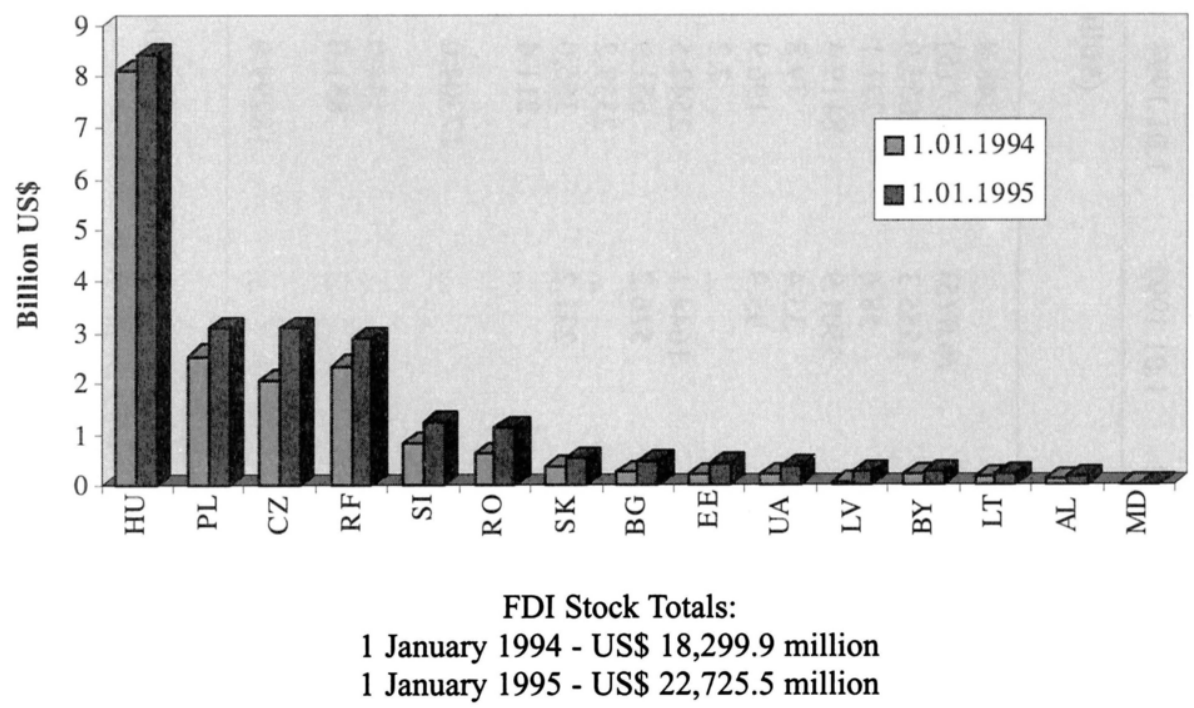

Source: UN/ECE Secretariat - National statistics.

Figure1. European transition economies: growth in foreign investment 
Table 1

Foreign (direct) investment stock in european transition economies by year

\begin{tabular}{|c|c|c|c|c|c|c|c|c|c|}
\hline & 1.01 .1992 & 1.01 .1993 & 1.01 .1994 & 1.01 .1995 & 1.04 .1995 & 1.07.1995 & 1992 & 1993 & 1994 \\
\hline COUNTRY & \multicolumn{6}{|c|}{ (Million US\$) } & \multicolumn{3}{|c|}{$\begin{array}{l}\text { ANNUAL GROWTH RATES } \\
\text { (PER CENT) }\end{array}$} \\
\hline Belarus (1) & $\ldots$ & $\ldots$ & 248.8 & 286.9 & $\ldots$ & $\ldots$ & $\ldots$ & $\ldots$ & 15.3 \\
\hline Bulgaria & $17.7(5)$ & $76.0(5)$ & $268.7(5)$ & 467.2 & $\ldots$ & $\ldots$ & 329.4 & 253.6 & 73.9 \\
\hline Czech Republic (2) & 595.1 & 1555.3 & 2053.0 & 3077.4 & $\ldots$ & $\ldots$ & 161.4 & 32.0 & 49.9 \\
\hline Estonia (2) & & 58.6 & 221.1 & 437.3 & $\ldots$ & $\ldots$ & $\ldots$ & 277.3 & 97.8 \\
\hline Hungary & 3137.0 & 5501.9 & 8119.4 & 8426.8 & $\ldots$ & $\ldots$ & 75.4 & 47.6 & 3.8 \\
\hline Latvia & $\ldots$ & 33.4 & 79.8 & 288.9 & $\ldots$ & $\ldots$ & $\ldots$ & 138.9 & 262.0 \\
\hline Lithuania (1) & 50.5 & 95.9 & 196.9 & $247.2(3)$ & $\ldots$ & $\ldots$ & 89.9 & 105.3 & 25.5 \\
\hline Moldova & $\ldots$ & $\ldots$ & 7.2 & 24.8 & 28.7 & $\ldots$ & $\ldots$ & $\ldots$ & 243.3 \\
\hline Poland & 479.5 & 1644.1 & 2542.5 & $3084.5(3)$ & $3284.5(3)$ & $\ldots$ & 242.9 & 54.6 & 21.3 \\
\hline Romania (1) & 225.8 & 516.2 & 651.9 & 1134.8 & 1221.0 & 1380.2 & 128.6 & 26.3 & 74.1 \\
\hline Russian Federation & $\ldots$ & $\ldots$ & 2337.2 & 2872.8 & 3074.7 & $\ldots$ & $\ldots$ & $\ldots$ & 22.9 \\
\hline Slovakia (1) & $\ldots$ & 231.2 & 366.0 & 551.7 & 565.4 & $\ldots$ & $\ldots$ & 58.3 & 50.7 \\
\hline Ukraine (2) & $\ldots$ & $\cdots$ & 211.4 & 366.9 & $\ldots$ & $\ldots$ & $\ldots$ & $\ldots$ & 73.6 \\
\hline SUB-TOTAL & $\cdots$ & $\ldots$ & 17304.0 & 21267.2 & $\ldots$ & $\ldots$ & $\cdots$ & $\cdots$ & 22.9 \\
\hline Albania & $\ldots$ & $\ldots$ & 144.0 & $200.0(4)$ & $\ldots$ & $\ldots$ & $\ldots$ & $\ldots$ & 38.9 \\
\hline Slovenia & $\ldots$ & $\ldots$ & 851.0 & 1258.3 & $\ldots$ & $\ldots$ & $\ldots$ & $\ldots$ & 47.9 \\
\hline TOTAL & $\ldots$ & $\ldots$ & 18299.0 & 22725.5 & $\ldots$ & $\ldots$ & $\begin{array}{l}\cdots \\
\cdots\end{array}$ & $\begin{array}{l}\cdots \\
\cdots\end{array}$ & 24.2 \\
\hline
\end{tabular}

Data unreported or not yet available.

(1) Cumulative foreign component of foreign investment enterprises' (FIEs') statutory capitals.

(2) Cumulative balance-of-payments FDI inflows.

(3) Preliminary data.

(4) Secretariat estimate.

(5) Revised data.

Note: Values in national currencies converted into US dollars at historical yearly (quarterly or half-yearly) average exchange rates.

Source: UN/ECE Secretariat - national statistics. 
final. This circumstance is particularly important in the cases of Hungary and Poland whose FDI stock figures for the end of 1994 are likely to be revised upwards. This being said, in 1994, at yearly average exchange rates, the FDI stock in the TEs for which the data are available rose by 4.4 bn US dollars (USD), that is from $18.3 \mathrm{bn}$ USD at the beginning of 1994 to 22.7 bn USD twelve months later, or by 24 per cent (see Table 1).

While data for longer time periods are not available for most of TEs, those referring to the leaders of market reforms in central Europe (the Czech Republic, Hungary, Poland and the Slovak Republic) show that the combined increments of FDI stock in these countries decreased in absolute terms from 4.7 bn USD in 1992 to 4.1 bn USD in 1993. In 1994, according to the preliminary data, the increment dropped dramatically by half and did not exceed 2.1 bn USD. The reduction in FDI growth rates in these countries broadly confirms an earlier finding by the UN/ECE secretariat based on the cash FDI inflows information (See Economic Survey of Europe in 1994-1995, pp. 151-153). At the same time, the revision of preliminary figures may, however, bring the estimates of FDI growth for 1994 upwards.

During 1994, FDI stocks grew the fastest in Latvia and Moldova, followed by Estonia, Romania and Bulgaria. One should take into account, however, that the small starting volumes of FDI in most of these countries tend to boost the growth rates as compared with those in countries which have already accumulated important amounts of FDI.

When comparing the structure of FDI stock by host economy, one should take into account both the preliminary nature and methodological differences of the individual country data available (see footnotes to Table 1). This being said, one notes that, amongst the European TEs, Hungary remains by far the most successful in attracting FDI. Although its share in the regional FDI stock dropped during 1994, in January 1995 this country still accounted for $37 \%$ of the total (44\% in January 1994). On the same date, the shares of the other major host countries - the Czech Republic, Poland and the Russian Federation - were stable and did not exceed $13-14 \%$ in each case.

From another angle, despite the growth slackening, the role of the TEs leading in market reforms as FDI host countries has remained preponderant. At the beginning of 1995, the Czech Republic, Hungary, Poland and the Slovak Republic accounted for over two-thirds of the total regional FDI stock. When the FDI stock in Slovenia is added, the combined weight of these five countries amounts to $72 \%$.

East-West Investment News is a sales publication (ISSN 1014-6911) which can be obtained from: UN Publications, CH-1211 Geneva 10, Switzerland, Fax: +41 22917 0027. 